\title{
GEOLOGICAL MAP OF THE WORLD
}

$\mathrm{T}$ HE Commission for the Geological Map of the World met in Paris during March 31-April 12. This Commission was founded in 1910 at the Stockholm International Congress and has been reorganized twice since the Second World War. At the Mexico International Geological Congress in 1956 two SubCommissions were created : (1) for the Tectonic Map of the World, and (2) for the Metallogenic Map of the World. The Paris meeting. was organized to establish an international basis and co-ordination for an immediate start on these three maps of the World : geological, tectonic and metallogenic, on an agreed universal scale, legend and principles of construction. The Commission's aim is to promote the construction of such maps for the following regions of the Earth : North America, South America, Europe, Africa, U.S.S.R., Asia, Oceania, Arctic and Antarctic. The Commission is planning to publish a Geological Atlas of the World at the scale $1: 10,000,000$ based on maps at the scale of $1: 5,000,000$. The latter scale is suggested for the tectonic and metallogenic maps. Detailed programmes for the realization of these maps were worked out by the Commission and a number of specific recommendations from various countries or groups of countries were accepted. The aim of the metallogenic map is to record the relations between geology, tectonics and the mineral deposits in any given region. It was also suggested that prior to the construction of such maps, mineral maps accompanied by indexes of mineral deposits should be prepared. It is hoped that these maps, at least in manuscript draft form will be ready for display at the International Geological Congress to be held in Copenhagen in 1960.

Sixty-one countries were represented at the Paris meeting by delegates and assisting geologists. The president of the Commission, elected in 1952, is
F. Blondel, who is assisted by his secretariat at 20, rue Monsieur, Paris $7 \mathrm{e}$, France. The vice-presidents for the selected regions are as follows: North and Central America, W. D. Johnston, jun.; South America, A. R. Lamego; Europe, A. Bentz; Africa, F. Dixey ; U.S.S.R., N. A. Beliaevsky ; Asia, V. P. Sondhi ; Oceania, J. M. Rayner.

A Select Committee under the presidency of $F$. Dixey examined suggestions for the general legend of the Geological Map of the World and drafted a set of recommendations. Similar work was done for the tectonic map by the special sub-commission (president, N. S. Shatsky ; secretary, A. A. Bogdanov), and for the metallogenic map by the special subcommission (president, W. D. Johnston, jun. ; secretary, P. Routhier). Possibilities of preparing a coal map of Europe were also discussed.

Besides the meetings of the Commissions, a number of meetings dealing with various associated problems were held, such as the International Geological Abstracting Service, presided over by H. M. E. Schurmann, the Committee on Stratigraphy, the Mediterranean-Alpine Committee and others.

During the fortnight's working of the Commission, a number of official receptions were held, which allowed a closer contact between the visiting geologists and their French colleagues, and the strenuous work of the Commission was relieved at the weekend by a visit to the cathedral towns and the castles of the Loire region. The meeting of such a number of geologists from so many countries, animated by the same enthusiasm and purpose, testifies to a most healthy situation in the world of international science. The effective and profitable results of the meeting are, in no small measure, due to the most efficient organization of the Commission by its president and secretariat.

\section{MUSEUMS ASSOCIATION CONFERENCE}

$\mathrm{T}$ HE sixty-fourth annual conference of the Museums Association was held in London during July 7-12, and was attended by more than 700 delegates, among whom were some 70 members of De Museumdag from Holland. It was held in Britain to enable the British delegates to return in some measure the hospitality and courtesy extended to them on their visit to Amsterdam in 1956

The meetings were held in the Beveridge Hall of the University of London and the official welcome was given by the Minister of Education (the Right Hon. Geoffrey Lloyd), who stressed the view of his Ministry that there should be more co-operation between local authorities and private bodies in the maintenance of museums. He welcomed the increasing part that museums were taking in the educational field and said that the Government was well aware of the difficulties of the small museum. Various suggestions had been made and meanwhile his Ministry was watching with interest the development of plans for a regional museum service.

During his presidential address Sir Philip Hendy, director of the National Gallery, dealt with various problems in the museum and art gallery field. First, he mentioned that the tremendous assistance given by the Carnegie United Kingdom Trust in the past is likely to be reduced in the future. He expressed the strong opinion of the Association that it should be replaced by Government assistance of a substantial nature. He then dealt with the recent controversy arising from the enlightened provisions of the Finance Act, 1956, whereby works of art could be accepted in payment of death duties. It was discouraging that a difference had arisen between local and national claims over the Chatsworth treasures. He believed that objects of the highest quality should go to the national collections, as they and they alone could provide the proper context and setting for such material. He also felt that the provisions of the Finance Act could be used for other objects that would be useful in building up the collections of local museums and would otherwise be almost certainly exported from Great Britain.

Dr. A. B. de Vries, president of De Museumdag, also spoke and enumerated some of the qualities necessary in a museum curator. 